\title{
Drying kinetics and mass transfer properties in the drying of thistle flower
}

\section{Cinética de secagem e propriedades de transferência de massa para a secagem da flor de cardo}

\author{
Raquel P. F. Guiné ${ }^{1 *}$ (D), Luísa Fontes ${ }^{2}$, Maria João Reis Lima ${ }^{1}$ \\ ${ }^{1}$ Centro de Estudos em Recursos Naturais e Ambiente, Instituto Politécnico de Viseu, Departamento de Indústrias \\ Alimentares, Viseu - Portugal \\ ${ }^{2}$ Instituto Politécnico de Viseu, Departamento de Indústrias Alimentares, Viseu - Portugal
}

*Corresponding Author: Raquel P. F. Guiné, Escola Superior Agrária de Viseu, Departamento de Indústrias Alimentares, Quinta da Alagoa, Estrada de Nelas, Ranhados, 3500-606, Viseu - Portugal, e-mail:

raquelguine@esav.ipv.pt

Cite as: Guiné, R. P. F., Fontes, L., \& Lima, M. J. R. (2019). Drying kinetics and mass transfer properties in the drying of thistle flower. Brazilian Journal of Food Technology, 22, e2019051. https://doi.org/10.1590/19816723.05119

\begin{abstract}
Thistle flowers, and particularly their stigmas, are used to coagulate milk in the production of a number of traditional Portuguese cheeses due to their high milk-clotting activity provided by the high content of aspartic proteases. The aim of the present work was to determine the mass transfer properties of thistle flower under different drying conditions: natural drying and convective drying. Convective drying took place in a convection chamber set at different temperatures $\left(35\right.$ to $65^{\circ} \mathrm{C}$ ) and the process was terminated when the sample presented a moisture content of about $5 \%$ or less. The traditional drying method was also used, placing the thistle flowers in a dry place sheltered from the sun, and leaving them to dehydrate at the variable room temperature. The present work allowed for the conclusion that convective drying was much faster than natural drying, and that the drying rate increased with temperature. The drying curve revealed an initial constant rate period followed by a falling rate. All the five thin layer models tested to fit the experimental data were shown to adequately describe the drying of the thistle flowers, but the best one was the Page model. The drying constant increased with temperature as did the effective diffusivity and the mass transfer coefficient. The results allowed one to estimate the activation energy for moisture diffusion $(57 \mathrm{~kJ} / \mathrm{mol})$ and for convective mass transfer $(78 \mathrm{~kJ} / \mathrm{mol})$. Thus this study showed the possibilities for designing efficient drying processes for the thistle flower used for milk-clotting in the manufacture of traditional cheeses.
\end{abstract}

Keywords: Activation energy; Convective drying; Diffusion coefficient; Mass transfer coefficient; Milk clotting; Thin layer model.

\section{Resumo}

A flor de cardo e, em particular, os seus estigmas, são utilizados para coagular o leite na produção de vários queijos tradicionais portugueses, devido à sua elevada atividade de coagulação, proporcionada pelo elevado teor de proteases aspárticas. $O$ objetivo do presente trabalho foi determinar as propriedades de transferência de massa da secagem de flor do cardo em diferentes condições: secagem natural e convectiva. A secagem convectiva decorreu em câmara de convecção a diferentes temperaturas $\left(35\right.$ a $\left.65^{\circ} \mathrm{C}\right)$ e o processo foi finalizado quando a amostra 
apresentava um teor de umidade de cerca de $5 \%$ ou inferior. Além disso, adotou-se também o método tradicional de secagem, colocando a flor de cardo em local seco e protegido do sol, deixando-a desidratar à temperatura ambiente variável. O presente trabalho permitiu concluir que a secagem convectiva foi muito mais rápida que a secagem natural e ainda que a velocidade de secagem aumentou com a temperatura. A curva de secagem revelou um período inicial de velocidade constante, seguido de fase de velocidade decrescente. Todos os cinco modelos de camada fina testados para se ajustarem aos dados experimentais revelaram descrever adequadamente a secagem da flor de cardo, no entanto, o modelo que se revelou melhor foi o de Page. A constante de secagem aumentou com a temperatura, assim como a difusidade efetiva e o coeficiente de transferência de massa. Os resultados permitiram estimar a energia de ativação para difusão de umidade $(57 \mathrm{~kJ} / \mathrm{mol})$ e para a transferência de massa por convecção $(78 \mathrm{~kJ} / \mathrm{mol})$. Desta forma, este estudo mostrou as possibilidades de projetar processos de secagem eficientes para a flor de cardo utilizada como coagulante do leite na fabricação de queijos tradicionais.

Palavras-chave: Energia de ativação; Secagem convectiva; Coeficiente de difusão; Coeficiente de transferência de massa; Coagulação do leite; Modelo de camada fina.

\section{Introduction}

The "Serra da Estrela" cheese is a Portuguese traditional product owing the Protected Designation of Origin (PDO) mention according to European and national legislation. It is highly valued owing to the smooth texture, intense flavour and rich bouquet, being appreciated both in Portugal and also abroad in some countries where it is already marketed. The "Serra da Estrela" cheese is very ancient and its manufacture still follows the traditional steps. It is produced with only three key ingredients: the raw milk from sheep Bordaleira da Serra da Estrela or Churra Mondegueira breeds, salt and dried thistle flower (Cynara cardunculus L.) which is used to coagulate the milk proteins. For the manufacture of Serra da Estrela cheese the milk is filtered, heated to around $30^{\circ} \mathrm{C}$, salted and the vegetable coagulant is added. The incorporation of the thistle flower into the cheese can follow two procedures: ground the flowers with salt or make an aqueous extract. The following steps include cutting the curd, moulding, pressing, salting the surface and ends with maturation, with variable times depending on the intended characteristics, and particularly texture (Carocho et al., 2016; Tavaria et al., 2004).

Wild thistle (Cardoon) is native to the Mediterranean areas and belongs to the family of Asteraceae. It has a pivotal role in the manufacture of many traditional Portuguese cheeses, being mandatory to use it as coagulant. The cardoon inflorescences, and particularly their stigma, are used because of their high milk-clotting activity provided by the high content in aspartic proteases (Barracosa et al., 2018; Dias et al., 2018). Furthermore, both wild and cultivated forms of cardoon have demonstrated to have added value owing to the presence of phenolic compounds with bioactive properties, particularly concentrated in the stigmas. With emphasis are highlighted the amounts of phenolic acids (mono and dicaffeoylquinic acids) as well as flavonoids (apigenin and luteolin derivatives) (Dias et al., 2018).

Modelling and simulation of drying processes is essential to determine the optimal operating conditions in order to have fast and efficient operations. Drying involves simultaneous heat and mass transfer, accompanied by physical and structural changes due to the loss of a considerable part of the water. To know the mass transfer properties allows to understand the process of water removal from the food, through diffusion and evaporation. There are different models available in the literature to predict the transfer phenomena occurring during drying of food products, being the diffusion models that describe the non-steady state transfer according to Fick's second law the most common (Cevoli et al., 2019; Guiné, 2008).

Modelling and simulation of drying processes is essential to determine the optimal operating conditions in order to have fast and efficient operations. Drying involves simultaneous heat and mass transfer, accompanied by physical and structural changes due to the loss of a considerable part of the 
water. To know the mass transfer properties allows to understand the process of water removal from the food, through diffusion and evaporation. There are different models available in the literature to predict the transfer phenomena occurring during drying of food products, being the diffusion models that describe the non-steady state transfer according to Fick's second law the most common (Cevoli et al., 2019; Guiné, 2008).

The thistle flower is used after drying and this operation can impart loss of some properties, and most especially due to oxidation in contact with drying air and high temperature, so it is important to design drying operations in order to be effective in preserving the thistle properties with minimal energy costs. The selection of the drying temperature is important in order avoid excessively high temperatures that could lead to loss of quality of the thistle flower, as for example the phenolic compounds that are known to degrade at temperatures above $80{ }^{\circ} \mathrm{C}$, or the loss of activity of the proteases, thus influencing the curding properties (Barracosa et al., 2018).

Hence, the objective of this work was to determine the mass transfer properties of thistle flower dried under different conditions: natural drying and convective drying at different temperatures in the range from 35 to $65^{\circ} \mathrm{C}$.

\section{Methods}

The thistle flower used for the experiments was Cynara cardunculus L. harvested in Viseu, Portugal, in early summer (June) at plain flowering stage. The initial moisture content was $57 \%$ (wet basis).

For the convective drying, the thistle flowers were placed in a convection chamber with ventilation (air velocity of $0.5 \mathrm{~m} / \mathrm{s}$ ) set at different temperatures $\left(35,45,55\right.$ and $65^{\circ} \mathrm{C}$ ) that were maintained constant for each experiment. Periodically, the samples were weighed for determination of moisture content. The interval of measurement was 20 minutes for the fastest dryings (temperatures of 55 and $65^{\circ} \mathrm{C}$ ) and 30 minutes for the slowest ones (temperatures of 34 and $45^{\circ} \mathrm{C}$ ). The end of drying was achieved when the sample presented a moisture content of about $5 \%$ or less. For each of the drying temperatures tested, two batches were made.

Because traditionally the thistle flower is dried naturally, experiments were also conducted in the same conditions of the natural drying, i.e., in the summer right after harvest by maintaining the thistle flower in a dry place sheltered from the sun. In this case the temperature was variable from day to day and also along the day/night cycle, but was not registered.

\section{Mathematical modelling}

\subsection{Modelling of drying kinetics by thin layer equations}

Thin-layer models are mathematical equations that relate the variations in moisture content along drying with some parameters, like for example the drying constant, $\mathrm{k}$ [1/s], or the lag factor, $\mathrm{k}_{0}$ [dimensionless], accounting for the combined effects of different transport phenomena which occur during drying.

The data obtained experimentally for each drying batch was plotted in the form of moisture ratio (MR) against time, in which MR is defined as Equation 1 (Guiné et al., 2011):

$M R=\left(W-W_{e}\right) /\left(W_{0}-W_{e}\right)$

where, $\mathrm{W}, \mathrm{W}_{\mathrm{e}}$ and $\mathrm{W}_{0}$ are, respectively, the moisture content at time $\mathrm{t}$, the equilibrium moisture content and the initial moisture content, all expressed in dry basis ( $\mathrm{g}$ water/g dry solids).

The experimental sets of (MR, t) were fitted using the software Sigma Plot (Version 14, SPSS, Inc.) to five thin layer models frequently cited in literature, as presented in Table 1. 
Table 1. Thin layer kinetic models from literature (Guiné et al., 2011).

\begin{tabular}{cc}
\hline Model & Equation ${ }^{1}$ \\
\hline Newton & MR $=\exp (-\mathrm{kt})$ \\
Page & MR $=\exp \left(-\mathrm{k} \mathrm{t} \mathrm{t}^{\mathrm{n}}\right)$ \\
Modified Page & $\mathrm{MR}=\exp \left(-(\mathrm{kt})^{\mathrm{n}}\right)$ \\
Henderson \& Pabis & $\mathrm{MR}=\mathrm{k}_{0} \exp (-\mathrm{kt})$ \\
Logarithmic & $\mathrm{MR}=\mathrm{k}_{0} \exp (-\mathrm{kt})+\mathrm{c}$ \\
\hline
\end{tabular}

${ }^{1} \mathrm{MR}=$ Moisture ratio $\left(M R=\left(W-W_{e}\right) /\left(W_{0}-W_{e}\right) \cdot \mathrm{k}=\right.$ Drying constant. $\mathrm{t}=$ Drying time. $\mathrm{k}_{0}, \mathrm{n}$ and $\mathrm{c}=$ Model constants.

To evaluate the quality of each estimation, several fitting indicators were used, namely the correlation coefficient (R), the standard error of estimate (SEE), the coefficient of variation for the drying constant (CV), the sum of squares (SS) and mean square (MS). Also, some statistical tests were performed, namely Shapiro Wilk test at a level of significance of $0.01 \%$ and the test for homogeneity of variances (Spearman Rank Correlation at $0.01 \%$ significance level).

\subsection{Diffusion model for mass transfer}

The Fick's second law of diffusion is widely used to predict the moisture distribution inside foods during drying (Nicolin et al., 2016, Equation 2):

$\frac{\partial W}{\partial t}=\frac{\partial}{\partial z}\left(\frac{1}{D_{e}} \frac{\partial W}{\partial z}\right)$

where $W$ is the dry basis moisture content $\left[\mathrm{kg}\right.$ water $/ \mathrm{kg}$ dry solids]; $t$ is time [s]; $D_{e}$ is effective diffusivity $\left[\mathrm{m}^{2} / \mathrm{s}\right]$; and $z$ is the characteristic dimension of the system $[\mathrm{m}]$, length in this case. This model can be simplified into (Haghi \& Amanifard, 2008, Equation 3):

$\frac{\partial W}{\partial t}=D_{e}\left(\frac{\partial^{2} W}{\partial z^{2}}\right)$

For the diffusion in transient conditions, the solution of Fick's Law can be approximated by an infinite series, of the form (Equation 4):

$M R=\frac{W-W_{e}}{W_{0}-W_{e}}=\frac{8}{\pi^{2}} \sum_{n=0}^{\infty} \frac{1}{(2 n+1)^{2}} \exp \left[-\frac{D_{e} t}{z^{2}} \frac{(2 n+1)^{2} \pi^{2}}{4}\right]$

When the Fourier numbers $\left(F o=D_{e} t / z^{2}\right)$ are higher than 0.2 the second and following terms of the series can be neglected, originating the following Equation 5:

$M R=\left(\frac{8}{\pi^{2}}\right) \exp \left[-D_{e} t\left(\frac{\pi^{2}}{4 z^{2}}\right)\right]$

that can be expressed in logarithm form corresponding to a straight line of the form:

$\ln (M R)=\ln \left(\frac{8}{\pi^{2}}\right)-\left(\frac{\pi^{2} D_{e}}{4 z^{2}}\right) t$

so that the value of $D_{e}$ can be calculated from the slope, and the slope itself can be interpreted as the drying constant $(k)$ while the intercept is linked to the lag factor $\left(k_{0}\right)$.

\subsection{Mass transfer correlations}

For Biot number for mass transfer higher than 0.1, the following correlation is valid (Dincer \& Hussain, 2002):

$B i_{m}=\frac{h_{m} z}{D_{e}}$

that allows estimate $h_{m}$, once known the value of $B i_{m}$ (Sahin et al., 2002). 
Dincer \& Hussain (2002) proposed an association between Biot number and Dincer Number:

$$
B i_{m}=\frac{24.848}{D i^{0.375}}
$$

in which:

$$
D i=\frac{u}{k z}
$$

with $u$ the flow velocity of drying air $[\mathrm{m} / \mathrm{s}], k$ the drying constant and $z$ the characteristic dimension.

\subsection{Calculation algorithm for the mass transfer properties}

The following procedure was adopted to estimate the mass transfer properties:

- Estimate $M R$ from the experimental drying data for every time $t$;

- From a plot $\ln (M R)=\mathrm{f}(t)$ estimate $k$ and $k_{0}$ from the slope and intercept (Equation 6);

- Estimate $D_{e}$ from the slope (Equation 6);

- Calculate $D_{i}$ (Equation 9);

- Calculate $B i_{m}$ (Equation 8);

- Calculate $h_{m}$ (Equation 7).

\subsection{Activation energy}

The variation of effective diffusivity with temperature follows an Arrhenius function (Guiné et al., 2012):

$$
D_{e}=D_{e}^{0} \exp \left(-\frac{E_{d}}{R(T+273.15)}\right)
$$

where $D_{e}{ }^{0}$ is the diffusivity for an infinite temperature; $E_{d}$ is the activation energy for moisture diffusion; $R$ is the constant of gases $\left(\mathrm{R}=8.31451 \mathrm{~J} \cdot \mathrm{mol}^{-1} \cdot \mathrm{K}^{-1}\right)$; and $T$ is the drying temperature (in $\left.{ }^{\circ} \mathrm{C}\right)$. A plot of $\ln \left(D_{e}\right)$ as a function of $(1 /(T+273.15))$ produces a straight line with slope equal to $\left(-E_{d} / R\right)$ and intercept equal to $\ln \left(D_{e}{ }^{0}\right)$, from which the parameters $E_{d}$ and $D_{e}{ }^{0}$ can be estimated (Guiné et al., 2012).

In parallel, the dependence of the convective mass transfer coefficient, $h_{m}$, from temperature can also be expressed by an Arrhenius function like:

$$
h_{m}=h_{m}^{0} \exp \left(\frac{E_{c}}{R(T+273.15)}\right)
$$

where $h_{m}{ }^{0}$ is the Arrhenius constant and $E_{c}$ is the activation energy for convective mass transfer.

Equations 10 and 11 can be linearized in the following way (Equations 12 and 13):

$$
\begin{aligned}
& \ln \left(D_{e}\right)=\ln \left(D_{e}^{o}\right)-\frac{E_{d}}{R(T+273.15)} \\
& \ln \left(h_{m}\right)=\ln \left(h_{m}^{o}\right)-\frac{E_{c}}{R(T+273.15)}
\end{aligned}
$$

\section{Results and discussion}

\subsection{Drying curves}

Figure 1 shows the drying curves of the thistle flower under different operating conditions, natural drying and convective drying with hot air at different temperatures. For each drying condition two independent runs were made, being the data represented in the graphs as different symbols. It was observed that for all 
temperatures there was a very straight proximity of the results obtained for the two independent dryings performed, being this even more pronounced for the natural drying, for which the points are practically coincident over the entire range of measurements. Furthermore, the drying curves show a typical trend for drying processes, with a first period of intense slope, corresponding to a fast initial removal of water at constant drying rate, followed by a period of falling rate in which the moisture content decreases more and more slowly as it approaches zero. The drying of many agricultural products follows this trend, as for example sweet potato (Onwude et al., 2019), mushroom (Das \& Arora, 2018), carrot (Kroehnke et al., 2018), onion, (Ostermeier et al., 2018), just to cite a few. In the constant drying rate period the drying rates $(\mathrm{dH} / \mathrm{dt})$ observed for the drying of thistle flower were $13.5 \mathrm{~g}$ water $/ \mathrm{h}$ at $35^{\circ} \mathrm{C}, 21.1 \mathrm{~g}$ water $/ \mathrm{h}$ at $45^{\circ} \mathrm{C}, 38.9 \mathrm{~g}$ water $/ \mathrm{h}$ at $55^{\circ} \mathrm{C}$ and $46.5 \mathrm{~g}$ water/h at $65{ }^{\circ} \mathrm{C}$, representing an increase of approximately $250 \%$ for a temperature step from 35 to $65^{\circ} \mathrm{C}$.
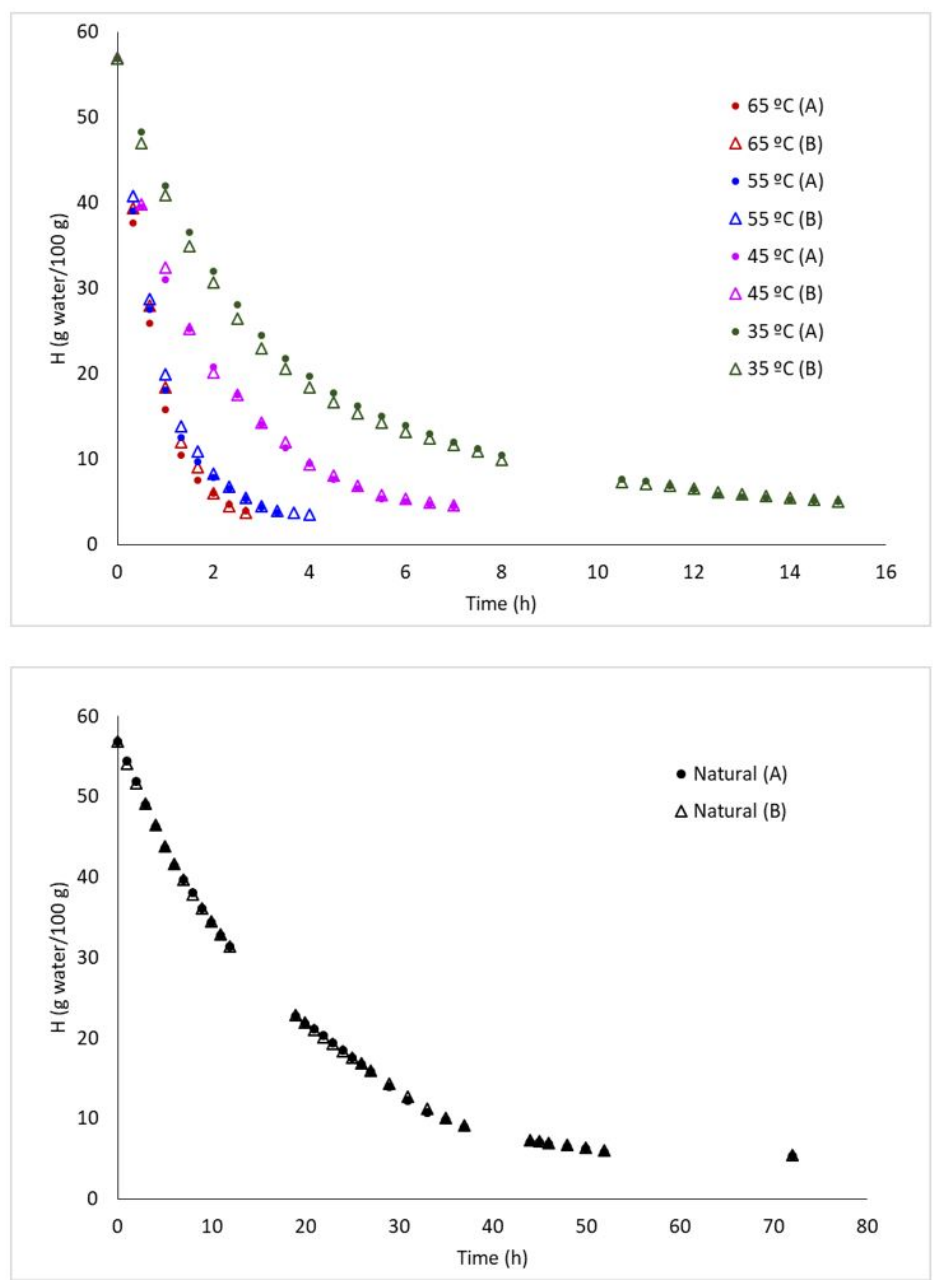

Figure 1. Drying curves: convective drying (top) and natural drying (bottom). The two independent runs for each temperature are identified as (A) and (B).

Regarding the drying time, it was observed that moisture content reached an equilibrium after about $50 \mathrm{~h}$ for the natural drying, taking considerable more time when compared with the convective drying (Figure 1). This is expected, because in the natural drying the flowers were kept in the shadow, and although it was summer time, the temperatures were not very high and were even lower during the night periods. On the contrary, the convective dryings occurred at constant temperature, and that value was maintained throughout the whole drying. By comparing the drying temperatures tested, the increase in temperature considerably decreased the time necessary to achieve the desired moisture content, although the differences for lower temperatures were more expressive as compared to those for higher temperature. The drying at $35{ }^{\circ} \mathrm{C}$ lasted 
$15 \mathrm{~h}$; an increase of $10^{\circ} \mathrm{C}$ (from 35 to $45^{\circ} \mathrm{C}$ ) in temperature reduced drying time by $8 \mathrm{~h}$, to a final time of $7 \mathrm{~h}$; another increase of $10^{\circ} \mathrm{C}$ reduced time by $3 \mathrm{~h}$, to only $4 \mathrm{~h}$, and finally the highest temperature tested $\left(65^{\circ} \mathrm{C}\right)$ allowed a reduction of $1.5 \mathrm{~h}$ in the drying time, to a very short time of only $2.5 \mathrm{~h}$. Similar variation trends were observed in other related studies for the convective drying of feijoa (Castro et al., 2019), yam (Srikanth et al., 2019) or garlic (Tao et al., 2018).

Hence, the choice of the drying temperature has a very important impact over the fastness of the process, but this gain in time must be weighed with the possible loss in quality if very high temperatures were used. Nevertheless, it is believed that mild temperatures, up to $50-60{ }^{\circ} \mathrm{C}$ do not influence the phenolic compounds or proteins, which might be degraded if at temperatures in the range $80-100{ }^{\circ} \mathrm{C}$ or higher (Correia et al., 2016; Guiné et al., 2017).

\subsection{Thin layer models}

Tables 2 to 6 show the results of the fitting procedure applied to the experimental data obtained for the different drying experiments. For the fitting, the experimental data used for each temperature consisted of the joint of both sets of data coming from the two independent runs performed, thus allowing to obtain a higher number of points for validation of the solutions. As previously mentioned, the fitting was made using the software Sigma Plot (V14) according to the models presented in Table 1. These equations were programmed on the software which found the best fitting solutions, i.e., the values of the model parameters that minimized the errors associated with the estimate.

Overall, it was observed that the estimates were good in all cases, with high values of the regression coefficient $(R)$, in some cases very close to 1 . Also the values of the coefficient of variation $(\mathrm{CV})$ were low (under $10 \%$ in all cases) and the standard error of estimate were very close to zero (SEE). The normality test and the test for homogeneity of variances were confirmed for all solutions and the results of the ANOVA were also very satisfactory. Because the results of ANOVA were the same since it was for the same experimental points, they were omitted in the following tables. All these criteria indicate that the fittings with the 5 models tested were all suitable, i.e., all of them described accurately the experimental data observed. Nevertheless, some minor differences were observed. For model Newton (Table 2), the values of $R$ ranged from 0.972 (at $35^{\circ} \mathrm{C}$ ) to 0.996 (at $65^{\circ} \mathrm{C}$ ) and the drying constant $(k)$ increased, as it should, with increasing temperature, since at higher temperatures the facility of water removal also increases due to increase in the diffusion properties of biological materials. The highest value for $k$ was $5.403 \times 10^{-4} \mathrm{~s}^{-1}$ for $65^{\circ} \mathrm{C}$.

Table 2. Results of fitting to model Newton.

\begin{tabular}{|c|c|c|c|c|c|}
\hline $\begin{array}{c}\text { Parameters } \\
\& \\
\text { Statistics } \\
\end{array}$ & Natural & $35^{\circ} \mathrm{C}$ & $45^{\circ} \mathrm{C}$ & $55^{\circ} \mathrm{C}$ & $65^{\circ} \mathrm{C}$ \\
\hline $\mathrm{K} \pm \mathrm{sd}^{1}$ & $\begin{array}{c}2.363 \times 10^{-5} \pm \\
4.639 \times 10^{-7}\end{array}$ & $\begin{array}{c}1.312 \times 10^{-4} \pm \\
4.842 \times 10^{-6}\end{array}$ & $\begin{array}{c}2.544 \times 10^{-4} \pm \\
1.383 \times 10^{-5}\end{array}$ & $\begin{array}{c}4.879 \times 10^{-4} \pm \\
1.628 \times 10^{-5}\end{array}$ & $\begin{array}{c}5.403 \times 10^{-4} \pm \\
1.768 \times 10^{-5}\end{array}$ \\
\hline $\mathrm{CV}^{2}(\%)$ & 1.963 & 3.689 & 5.435 & 3.336 & 3.272 \\
\hline $\mathrm{NI}^{3}$ & 8 & 9 & 10 & 8 & 7 \\
\hline $\mathrm{R}^{4}$ & 0.990 & 0.972 & 0.975 & 0.994 & 0.996 \\
\hline $\mathrm{SEE}^{5}$ & 0.039 & 0.053 & 0.057 & 0.031 & 0.029 \\
\hline Normality $^{6}$ & Pass (0.791) & Pass (0.785) & Pass (0.695) & Pass (0.805) & Pass $(0.820)$ \\
\hline $\mathrm{HV}$ test $^{7}$ & Pass (0.969) & Pass (0.832) & Pass (0.414) & Pass (0.099) & Pass $(0.205)$ \\
\hline ANOVA SS ${ }^{8}$ & 10.987 & 4.839 & 3.090 & 2.821 & 1.624 \\
\hline ANOVA MS ${ }^{9}$ & 0.162 & 0.090 & 0.103 & 0.118 & 0.096 \\
\hline
\end{tabular}

${ }^{1} \mathrm{~K}$, sd $=$ drying constant and corresponding standard deviation. ${ }^{2} \mathrm{CV}=$ Coefficient of variation for drying constant estimation. ${ }^{3} \mathrm{NI}=\mathrm{Number}$ of iterations. ${ }^{4} \mathrm{R}=$ Regression coefficient. ${ }^{5} \mathrm{SEE}=$ Standard error of estimate. ${ }^{6}$ Shapiro Wilk test for normality at 0.0001 significance level. ${ }^{7} \mathrm{HV}=$ Homogeneity of variances (Spearman Rank Correlation at 0.0001 significance level). ${ }^{8} \mathrm{SS}=$ Sum of squares. ${ }^{9} \mathrm{MS}=$ Mean square.

For model Henderson \& Pabis (Table 3), the values of $R$ were even higher than those for model Newton (between 0.978 and 0.996 ) and the highest value of the drying constant was very similar to that obtained with the previous fitting for model Newton, $5.307 \times 10^{-4} \mathrm{~s}^{-1}$, also obtained for the highest temperature of $65^{\circ} \mathrm{C}$. Furthermore, the values obtained for constant $n$ were very similar for all drying conditions tested. 
Table 3. Results of fitting to model Henderson \& Pabis.

\begin{tabular}{cccccc}
\hline Parameters \& & \multicolumn{5}{c}{ Drying conditions } \\
\cline { 2 - 6 } Statistics & Natural & $\mathbf{3 5}^{\circ} \mathbf{C}$ & $\mathbf{4 5}^{\circ} \mathbf{C}$ & $\mathbf{5 5}{ }^{\circ} \mathbf{C}$ & $\mathbf{6 5}^{\circ} \mathbf{C}$ \\
\hline $\mathrm{n} \pm \mathrm{sd}^{1}$ & $9.236 \times 10^{-1} \pm$ & $8.925 \times 10^{-1} \pm$ & $9.208 \times 10^{-1} \pm$ & $9.765 \times 10^{-1} \pm$ & $9.818 \times 10^{-1} \pm$ \\
& $1.163 \times 10^{-2}$ & $2.520 \times 10^{-2}$ & $3.396 \times 10^{-2}$ & $2.047 \times 10^{-2}$ & $1.948 \times 10^{-2}$ \\
$\mathrm{~K} \pm \mathrm{sd}^{2}$ & $2.129 \times 10^{-5} \pm$ & $1.142 \times 10^{-4} \pm$ & $2.302 \times 10^{-4} \pm$ & $4.762 \times 10^{-4} \pm$ & $5.307 \times 10^{-4} \pm$ \\
$\mathrm{CV}^{3}(\%)$ & $4.712 \times 10^{-7}$ & $5.099 \times 10^{-6}$ & $1.458 \times 10^{-5}$ & $1.835 \times 10^{-5}$ & $1.991 \times 10^{-5}$ \\
$\mathrm{NI}^{4}$ & 2.213 & 4.464 & 6.334 & 3.854 & 3.753 \\
$\mathrm{R}^{5}$ & 9 & 13 & 13 & 10 & 9 \\
$\mathrm{SEE}^{6}$ & 0.994 & 0.978 & 0.978 & 0.994 & 0.996 \\
Normality $^{7}$ & 0.031 & 0.047 & 0.053 & 0.031 & 0.029 \\
$\mathrm{HV} \mathrm{test}^{8}$ & Pass $(0.881)$ & Pass $(0.869)$ & Pass $(0.737)$ & Pass $(0.769)$ & Pass $(0.771)$ \\
\hline
\end{tabular}

${ }^{1} \mathrm{n}, \mathrm{sd}=$ model parameter and corresponding standard deviation. ${ }^{2} \mathrm{~K}, \mathrm{sd}=$ drying constant and corresponding standard deviation. ${ }^{3} \mathrm{CV}=\mathrm{Coefficient}$ of variation for drying constant estimation. ${ }^{4} \mathrm{NI}=$ Number of iterations. ${ }^{5} \mathrm{R}=$ Regression coefficient. ${ }^{6} \mathrm{SEE}=$ Standard error of estimate. ${ }^{7}$ Shapiro Wilk test for normality at 0.0001 significance level. ${ }^{8} \mathrm{HV}=$ Homogeneity of variances (Spearman Rank Correlation at 0.0001 significance level).

Table 4 shows the results obtained for fitting using model Page, which, together with model Modified page (Table 5) showed the highest values for the regression coefficient, varying from a minimum of 0.997 to a maximum of 0.999 , being practically perfect. As it can be seen from the Tables 4 and 5 the fittings made with these two equation converged to very similar solutions in terms of the independent parameter, with equal values for $n$ in all cases, but with different values for the drying constant. Also, the Modified Page equation allowed a faster convergence, as seen by the lower number of iterations needed to reach the final convergence.

Table 4. Results of fitting to model Page.

\begin{tabular}{cccccc}
\hline Parameters \& & \multicolumn{5}{c}{ Drying conditions } \\
\cline { 2 - 6 } Statistics & Natural & $\mathbf{3 5}^{\circ} \mathbf{C}$ & $\mathbf{4 5}^{\circ} \mathbf{C}$ & $\mathbf{5 5}^{\circ} \mathbf{C}$ & $\mathbf{6 5}^{\circ} \mathbf{C}$ \\
\hline $\mathrm{n} \pm \mathrm{sd}^{1}$ & $7.999 \times 10^{-1} \pm$ & $6.493 \times 10^{-1} \pm$ & $6.120 \times 10^{-1} \pm$ & $7.637 \times 10^{-1} \pm$ & $7.934 \times 10^{-1} \pm$ \\
& $7.299 \times 10^{-3}$ & $1.226 \times 10^{-2}$ & $6.109 \times 10^{-3}$ & $2.010 \times 10^{-2}$ & $2.145 \times 10^{-2}$ \\
$\mathrm{~K} \pm \mathrm{sd}^{2}$ & $2.027 \times 10^{-4} \pm$ & $3.237 \times 10^{-3} \pm$ & $7.075 \times 10^{-3} \pm$ & $3.147 \times 10^{-3} \pm$ & $2.711 \times 10^{-3} \pm$ \\
$\mathrm{CV}^{3}(\%)$ & $1.604 \times 10^{-5}$ & $3.732 \times 10^{-4}$ & $3.821 \times 10^{-4}$ & $5.107 \times 10^{-4}$ & $4.614 \times 10^{-4}$ \\
$\mathrm{NI}^{4}$ & 7.913 & 1.153 & 5.400 & 1.623 & 1.702 \\
$\mathrm{R}^{5}$ & 18 & 23 & 22 & 18 & 15 \\
$\mathrm{SEE}^{6}$ & 0.999 & 0.997 & 0.999 & 0.999 & 0.999 \\
Normality $^{7}$ & 0.012 & 0.017 & 0.006 & 0.014 & 0.013 \\
$\mathrm{HV}_{\text {test }}{ }^{8}$ & Pass $(0.944)$ & Pass $(0.952)$ & Pass $(0.968)$ & Pass $(0.977)$ & Pass $(0.945)$ \\
\hline
\end{tabular}

${ }^{1} \mathrm{n}, \mathrm{sd}=$ Model parameter and corresponding standard deviation. ${ }^{2} \mathrm{~K}$, sd = Drying constant and corresponding standard deviation. ${ }^{3} \mathrm{CV}=$ Coefficient of variation for drying constant estimation. ${ }^{4} \mathrm{NI}=$ Number of iterations. ${ }^{5} \mathrm{R}=$ Regression coefficient. ${ }^{6} \mathrm{SEE}=\mathrm{Standard}$ error of estimate. ${ }^{7}$ Shapiro Wilk test for normality at 0.0001 significance level. ${ }^{8} \mathrm{HV}=$ Homogeneity of variances (Spearman Rank Correlation at 0.0001 significance level).

Table 5. Results of fitting to model Modified Page.

\begin{tabular}{|c|c|c|c|c|c|}
\hline \multirow{2}{*}{$\begin{array}{c}\text { Parameters \& } \\
\text { Statistics }\end{array}$} & \multicolumn{5}{|c|}{ Drying conditions } \\
\hline & Natural & $35^{\circ} \mathrm{C}$ & $45^{\circ} \mathrm{C}$ & $55^{\circ} \mathrm{C}$ & $65^{\circ} \mathrm{C}$ \\
\hline $\mathrm{n} \pm \mathrm{sd}^{1}$ & $\begin{array}{c}7.999 \times 10^{-1} \pm \\
7.299 \times 10^{-3}\end{array}$ & $\begin{array}{c}6.493 \times 10^{-1} \pm \\
1.226 \times 10^{-2}\end{array}$ & $\begin{array}{c}6.120 \times 10^{-1} \pm \\
6.109 \times 10^{-3}\end{array}$ & $\begin{array}{c}7.637 \times 10^{-1} \pm \\
2.010 \times 10^{-2}\end{array}$ & $\begin{array}{c}7.934 \times 10^{-1} \pm \\
2.145 \times 10^{-2}\end{array}$ \\
\hline $\mathrm{K} \pm \mathrm{sd}^{2}$ & $\begin{array}{c}2.416 \times 10^{-5} \pm \\
1.735 \times 10^{-7}\end{array}$ & $\begin{array}{c}1.464 \times 10^{-4} \pm \\
2.643 \times 10^{-6}\end{array}$ & $\begin{array}{c}3.064 \times 10^{-4} \pm \\
3172 \times 10^{-6}\end{array}$ & $\begin{array}{c}5.293 \times 10^{-4} \pm \\
1.150 \times 10^{-5}\end{array}$ & $\begin{array}{c}5.816 \times 10^{-4} \pm \\
1.206 \times 10^{-5}\end{array}$ \\
\hline $\mathrm{CV}^{3}(\%)$ & 0.718 & 1.805 & 1.035 & 2.173 & 2.074 \\
\hline $\mathrm{NI}^{4}$ & 6 & 7 & 7 & 8 & 7 \\
\hline $\mathrm{R}^{5}$ & 0.999 & 0.997 & 0.999 & 0.999 & 0.999 \\
\hline $\mathrm{SEE}^{6}$ & 0.012 & 0.017 & 0.006 & 0.014 & 0.013 \\
\hline Normality $^{7}$ & Pass (0.944) & Pass (0.952) & Pass (0.968) & Pass (0.977) & Pass $(0.945)$ \\
\hline $\mathrm{HV}$ test $^{8}$ & Pass $(0.384)$ & Pass $(0.183)$ & Pass $(0.288)$ & Pass (0.104) & Pass $(0.921)$ \\
\hline
\end{tabular}


Finally, Table 6 shows the results obtained for the last model tested, Logarithmic, and these show that once again the quality of the estimates was very high, with values of $R$ in the range 0.991 to 0.999 . The values of the drying constant for this model were similar as for other models, with the highest value obtained for $65^{\circ} \mathrm{C}$, being $6.098 \times 10^{-4} \mathrm{~s}^{-1}$.

Table 6. Results of fitting to model Logarithmic.

\begin{tabular}{cccccc}
\hline Parameters \& & \multicolumn{5}{c}{ Drying conditions } \\
\cline { 2 - 6 } Statistics & Natural & $\mathbf{3 5}^{\circ} \mathbf{C}$ & $\mathbf{4 5}^{\circ} \mathbf{C}$ & $\mathbf{5 5}{ }^{\circ} \mathbf{C}$ & $\mathbf{6 5}^{\circ} \mathbf{C}$ \\
\hline \multirow{2}{*}{$\mathrm{K}_{0} \pm \mathrm{sd}^{1}$} & $9.052 \times 10^{-1} \pm$ & $8.835 \times 10^{-1} \pm$ & $9.002 \times 10^{-1} \pm$ & $9.517 \times 10^{-1} \pm$ & $9.543 \times 10^{-1} \pm$ \\
& $7.528 \times 10^{-3}$ & $4.734 \times 10^{-3}$ & $6.109 \times 10^{-3}$ & $9.834 \times 10^{-3}$ & $1.201 \times 10^{-2}$ \\
$\mathrm{n} \pm \mathrm{sd}^{2}$ & $5.831 \times 10^{-2} \pm$ & $6.315 \times 10^{-2} \pm$ & $6.345 \times 10^{-2} \pm$ & $3.977 \times 10^{-2} \pm$ & $3.928 \times 10^{-2} \pm$ \\
& $4.319 \times 10^{-3}$ & $4.734 \times 10^{-3}$ & $2.372 \times 10^{-2}$ & $4.037 \times 10^{-3}$ & $6.131 \times 10^{-3}$ \\
$\mathrm{~K} \pm \mathrm{sd}^{3}$ & $2.670 \times 10^{-5} \pm$ & $1.536 \times 10^{-4} \pm$ & $3.112 \times 10^{-4} \pm$ & $5.525 \times 10^{-4} \pm$ & $6.098 \times 10^{-4} \pm$ \\
$\mathrm{CV}^{4}(\%)$ & $5.603 \times 10^{-7}$ & $4.851 \times 10^{-6}$ & $1.761 \times 10^{-5}$ & $1.286 \times 10^{-5}$ & $1.860 \times 10^{-5}$ \\
$\mathrm{NI}^{5}$ & 2.098 & 3.158 & 5.659 & 2.328 & 3.051 \\
$\mathrm{R}^{6}$ & 9 & 10 & 10 & 7 & 8 \\
$\mathrm{SEE}^{7}$ & 0.999 & 0.994 & 0.991 & 0.999 & 0.999 \\
Normality $^{8}$ & 0.018 & 0.025 & 0.034 & 0.014 & 0.016 \\
$\mathrm{HV}_{\text {test }}{ }^{5}$ & Pass $(0.951)$ & Pass $(0.962)$ & Pass $(0.902)$ & Pass $(0.920)$ & Pass $(0.930)$ \\
\hline
\end{tabular}

${ }^{1} \mathrm{~K}_{0}, \mathrm{sd}=$ Model factor and corresponding standard deviation. ${ }^{2} \mathrm{n}, \mathrm{sd}=$ Model parameter and corresponding standard deviation. ${ }^{3} \mathrm{~K}, \mathrm{sd}=$ Drying constant and corresponding standard deviation. ${ }^{4} \mathrm{CV}=$ Coefficient of variation for drying constant estimation. ${ }^{5} \mathrm{NI}=$ Number of iterations. ${ }^{6} \mathrm{R}=$ Regression coefficient. ${ }^{7} \mathrm{SEE}=$ Standard error of estimate. ${ }^{8}$ Shapiro Wilk test for normality at 0.0001 significance level. ${ }^{9} \mathrm{HV}=$ Homogeneity of variances (Spearman Rank Correlation at 0.0001 significance level).

Figure 2 shows the fitting results together with the experimental points for all drying conditions tested, and reveals that in all cases the model predictions (lines) are very much coincident with the experimental observations (points), confirming what was previously described by analyzing the results of Tables 2 to 6 . 

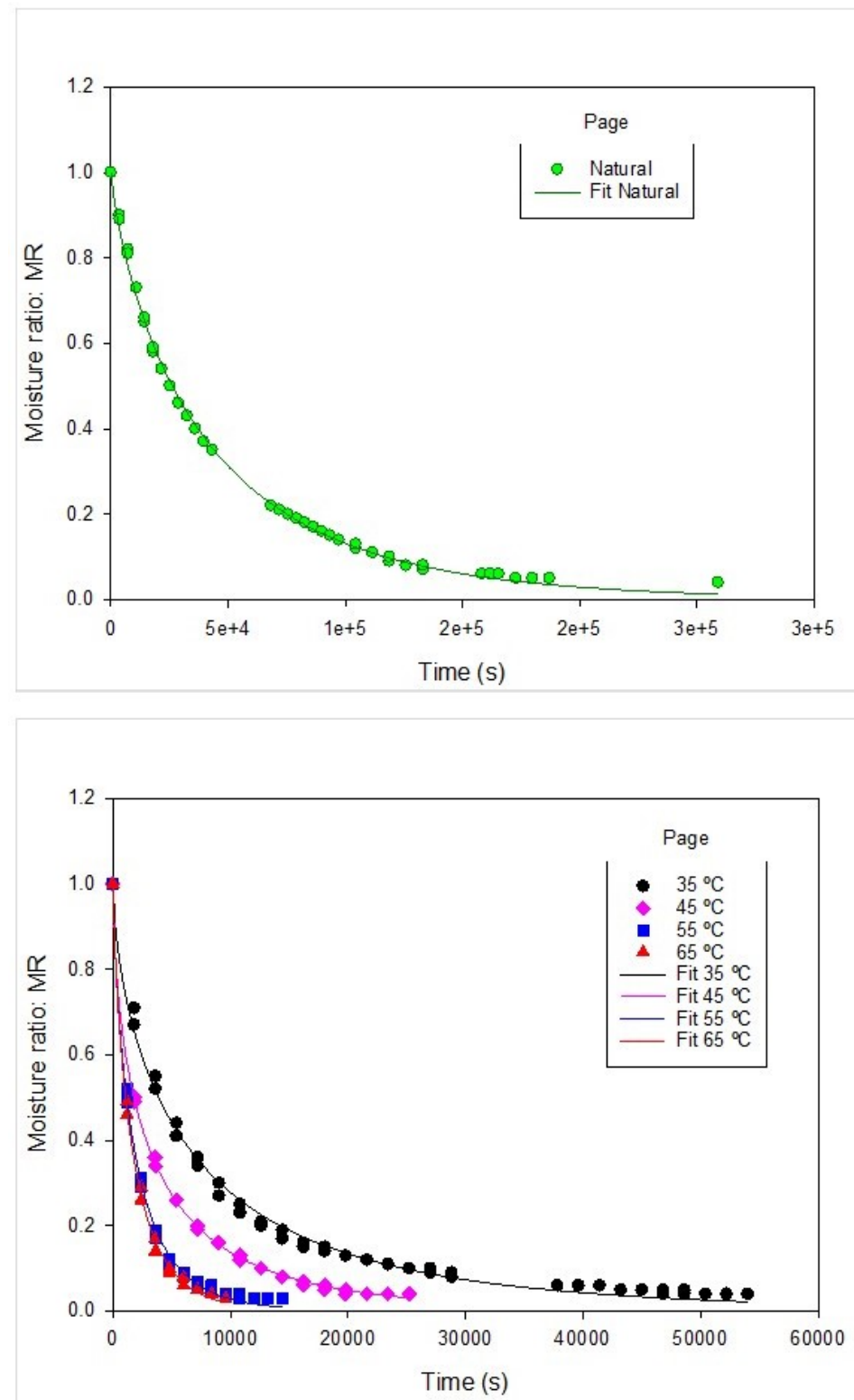

Figure 2. Fitting for model Page: natural drying (top) and convective drying (bottom).

Figure 3 shows the values obtained for the drying constant in the different conditions tested (natural and convective drying) and the different models evaluated, except the values obtained for model Page, because those stand in a range much different than all others, and therefore it would not be suitable to represent those in the same scale. The results indicate clearly an increase of the drying constant with increasing temperature, and considering that natural drying was on average at a lower temperature than $35^{\circ} \mathrm{C}$, for being on the shadow during the day and at much lower temperatures during the night. This increase in drying constant was also reported by other authors for the convective drying of different agricultural products: drying of onion in the temperature range from $30^{\circ} \mathrm{C}$ to $70{ }^{\circ} \mathrm{C}$ (Guiné et al., 2011) or drying of pears in the range $30{ }^{\circ} \mathrm{C}$ to $60{ }^{\circ} \mathrm{C}$ (Mota et al., 2010). Furthermore, the same increase in temperature $\left(10^{\circ} \mathrm{C}\right)$ has a less pronounced effect on the drying constant for the highest temperatures, as seen for example in the deep increase from $45^{\circ} \mathrm{C}$ to $55^{\circ} \mathrm{C}$ as compared with that observed between $55{ }^{\circ} \mathrm{C}$ and $65{ }^{\circ} \mathrm{C}$. This might be due to some effect of high temperatures on the matrix for moisture diffusion, and due to possible partial collapsing of the internal structure of the material. 


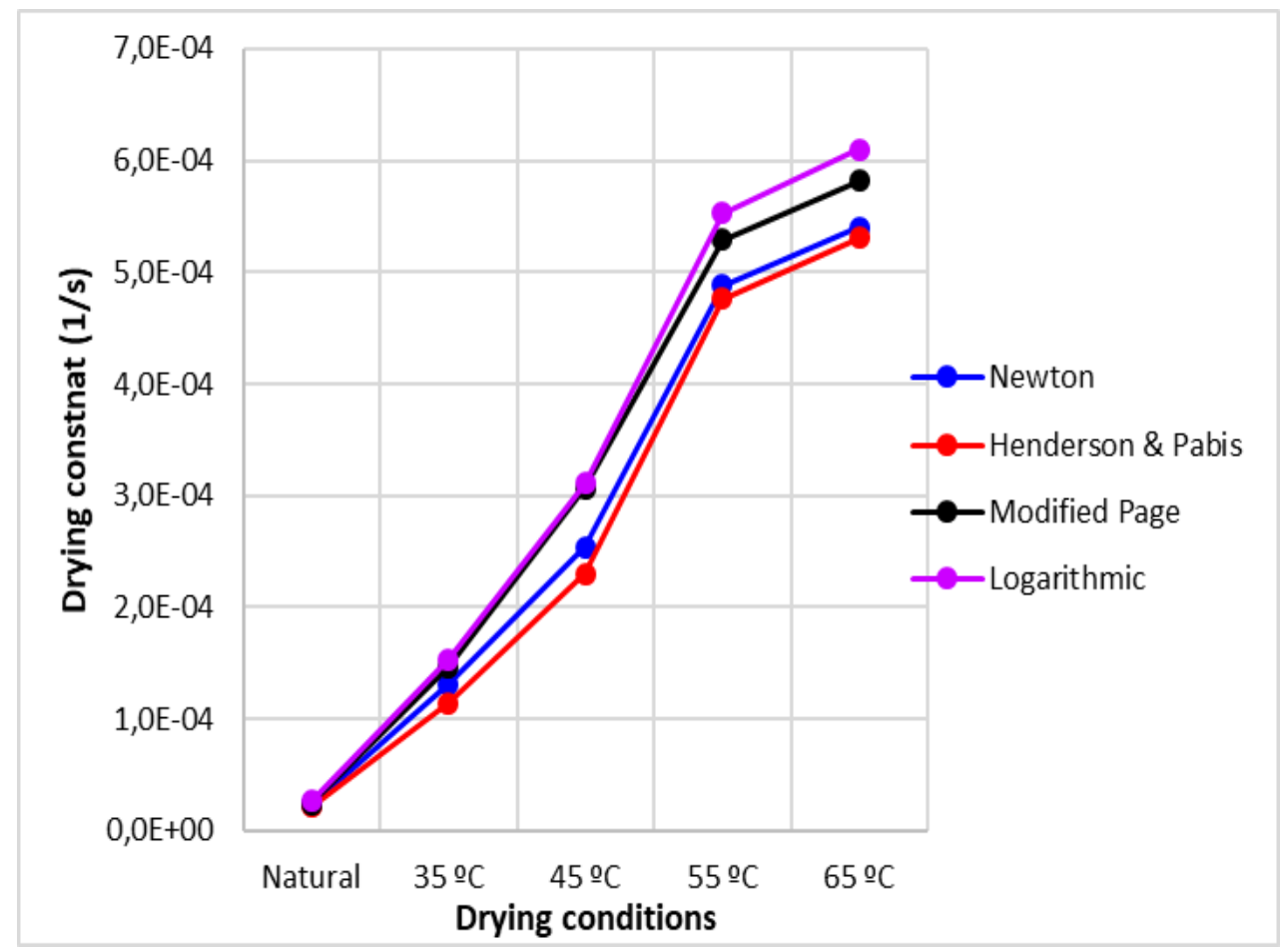

Figure 3. Variation of drying constant with temperature.

\subsection{Mass transfer properties and activation energy}

Table 7 shows the mass transfer properties for the drying of thistle flower, calculated through the algorithm presented earlier. The values of diffusion coefficient increased importantly with temperature, because heat facilitates the permeabilization of tissues allowing an easier transport of the moisture vapour from the inside to the surface. The values of diffusivity are of the same order of magnitude as those reported for the drying of mushroom (Das \& Arora, 2018), longan (Apinyavisit et al., 2018) or kiwi (Mohammadi et al., 2019). Also the drying constant increased, meaning faster processes as the drying temperature raised, and finally, also the mass transfer coefficients increased with drying temperature, accordingly with the other mass transfer properties.

Table 7. Mass transfer properties for the drying of thistle flower.

\begin{tabular}{cccccc}
\hline Drying & $\mathbf{D e}^{\mathbf{1}}$ & $\mathbf{K}^{\mathbf{2}}$ & $\mathbf{D i}^{\mathbf{3}}$ & $\mathbf{B i}^{4}$ & $\mathbf{h}_{\mathbf{m}}^{\mathbf{5}}$ \\
\hline Temperature & $\left(\mathbf{m}^{\mathbf{2}} / \mathbf{s}\right)$ & $\left.\mathbf{s}^{-1}\right)$ & & & $\mathbf{( m / s )}$ \\
\hline Natural & $5.347 \times 10^{-11}$ & $1.466 \times 10^{-5}$ & $1.137 \times 10^{7}$ & 0.056 & $1.001 \times 10^{-9}$ \\
$35^{\circ} \mathrm{C}$ & $1.902 \times 10^{-10}$ & $5.215 \times 10^{-5}$ & $3.196 \times 10^{6}$ & 0.090 & $5.731 \times 10^{-9}$ \\
$45^{\circ} \mathrm{C}$ & $4.456 \times 10^{-10}$ & $1.222 \times 10^{-4}$ & $1.364 \times 10^{6}$ & 0.124 & $1.847 \times 10^{-8}$ \\
$55^{\circ} \mathrm{C}$ & $9.213 \times 10^{-10}$ & $2.562 \times 10^{-4}$ & $6.599 \times 10^{5}$ & 0.163 & $5.015 \times 10^{-8}$ \\
$65^{\circ} \mathrm{C}$ & $1.300 \times 10^{-9}$ & $3.563 \times 10^{-4}$ & $4.677 \times 10^{5}$ & 0.186 & $8.049 \times 10^{-8}$ \\
\hline
\end{tabular}

${ }^{1} \mathrm{D}_{\mathrm{e}}=$ Effective diffusivity. ${ }^{2} \mathrm{~K}=$ Drying constant. ${ }^{3} \mathrm{Di}=$ Dincer number. ${ }^{4} \mathrm{Bi}=$ Biot number. ${ }^{5} \mathrm{hm}=$ Convective mass transfer coefficient.

The values in Table 8 refer to the activation energy calculated for moisture diffusion and mass transfer, by Equations 12 and 13, respectively. The value of activation energy for moisture diffusion was $56.48 \mathrm{~kJ} / \mathrm{mol}$ while the activation energy for mass convective transfer at the surface was $77.66 \mathrm{~kJ} / \mathrm{mol}$. These values are within the same range as those reported for other foods, like pears (Guiné et al., 2013), kiwi (Mohammadi et al., 2019), sweet potato (Onwude et al., 2019) or pumpkin (Guiné et al., 2012). These values indicate that internal diffusion of moisture was not the limiting factor for the drying of thistle flower (Guiné et al., 2013). 
Table 8. Activation energy for moisture diffusion and for convective mass transfer of thistle flower.

\begin{tabular}{|c|c|c|c|}
\hline Moisture diffusion ${ }^{1}$ & Value & Convective mass transfer ${ }^{2}$ & Value \\
\hline $\mathrm{De}_{\mathrm{e}}^{0}\left(\mathrm{~m}^{2} / \mathrm{s}\right)$ & 0.779 & $\mathrm{H}_{\mathrm{m}}{ }^{0}\left(\mathrm{~m}^{2} / \mathrm{s}\right)$ & 94448 \\
\hline $\mathrm{E}_{\mathrm{c}}(\mathrm{kJ} / \mathrm{mol})$ & 56.48 & $\mathrm{E}_{\mathrm{c}}(\mathrm{kJ} / \mathrm{mol})$ & 77.66 \\
\hline
\end{tabular}

${ }^{1} \mathrm{D}_{\mathrm{e}}{ }^{0}=$ Diffusivity for an infinite temperature. $\mathrm{E}_{\mathrm{c}}=$ Activation energy for moisture diffusion. ${ }^{2} \mathrm{Hm}^{0}=$ Arrhenius constant. $\mathrm{E}_{\mathrm{c}}=$ Activation energy for convective mass transfer.

\section{Conclusions}

The present work allowed concluding that the convective drying was much faster as compared with natural drying, and increase in the temperature of hot air also increased the drying rate, which presented an initial constant rate period followed by a stage of falling rate. From the five thin layer models tested to fit the experimental data, all revealed to adequately describe the drying of thistle flower, but, nevertheless, the models that was best was Modified Page. The drying constant increased with temperature and so did the effective diffusivity and the mass transfer coefficient. The results allowed estimating the activation energy for moisture diffusion $(57 \mathrm{~kJ} / \mathrm{mol})$ and for convective mass transfer $(78 \mathrm{~kJ} / \mathrm{mol})$.

\section{Acknowledgements}

This work was prepared in the ambit of the project approved and financed by Portuguese Foundation for Science and Technology (FCT) with reference 02/SAICT/2016/23290, titled "QClasse: Caracterização e Valorização da autenticidade do QSE DOP e sua vocação para a promoção da Saúde”.

\section{References}

Apinyavisit, K., Nathakaranakule, A., Mittal, G. S., \& Soponronnarit, S. (2018). Heat and mass transfer properties of longan shrinking from a spherical to an irregular shape during drying. Biosystems Engineering, 169, 11-21. http://dx.doi.org/10.1016/j.biosystemseng.2018.01.007

Barracosa, P., Oliveira, J., Barros, M., \& Pires, E. (2018). Morphological evaluation of cardoon (Cynara cardunculus L.): Assessing biodiversity for applications based on tradition, innovation and sustainability. Genetic Resources and Crop Evolution, 65(1), 17-28. http://dx.doi.org/10.1007/s10722-017-0579-0

Carocho, M., Barros, L., Barreira, J. C. M., Calhelha, R. C., Soković, M., Fernández-Ruiz, V., Buelga, C. S., Morales, P., \& Ferreira, I. C. F. R. (2016). Basil as functional and preserving ingredient in "Serra da Estrela" cheese. Food Chemistry, 207, 5159. PMid:27080879. http://dx.doi.org/10.1016/j.foodchem.2016.03.085

Castro, A. M., Mayorga, E. Y., \& Moreno, F. L. (2019). Mathematical modelling of convective drying of feijoa (Acca sellowiana Berg) slices. Journal of Food Engineering, 252, 44-52. http://dx.doi.org/10.1016/j.jfoodeng.2019.02.007

Cevoli, C., Chakravartula, S. S. N., Rosa, M. D., \& Fabbri, A. (2019). Drying of coating on bun bread: Heat and mass transfer numerical model. Biosystems Engineering, 181, 1-10. http://dx.doi.org/10.1016/j.biosystemseng.2019.02.009

Correia, P., Vítor, A., Tenreiro, M., Correia, A. C., Madanelo, J., \& Guiné, R. (2016). Effect of different thistle flower ecotypes as milk-clotting in Serra da Estrela cheese. Nutrition \& Food Science, 46(4), 458-475. http://dx.doi.org/10.1108/NFS-12-2015-0157

Das, I., \& Arora, A. (2018). Alternate microwave and convective hot air application for rapid mushroom drying. Journal of Food Engineering, 223, 208-219. http://dx.doi.org/10.1016/j.jfoodeng.2017.10.018

Dias, M. I., Barros, L., Barreira, J. C. M., Alves, M. J., Barracosa, P., \& Ferreira, I. C. F. R. (2018). Phenolic profile and bioactivity of cardoon (Cynara cardunculus L.) inflorescence parts: Selecting the best genotype for food applications. Food Chemistry, 268, 196-202. PMid:30064748. http://dx.doi.org/10.1016/j.foodchem.2018.06.081

Dincer, I., \& Hussain, M. M. (2002). Development of a new Bi-Di correlation for solids drying. International Journal of Heat and Mass Transfer, 45(15), 3065-3069. http://dx.doi.org/10.1016/S0017-9310(02)00031-5

Guiné, R. P. F. (2008). Pear drying: Experimental validation of a mathematical prediction model. Food and Bioproducts Processing, 86(4), 248-253. http://dx.doi.org/10.1016/j.fbp.2007.11.001

Guiné, R. P. F., Barroca, M. J., \& Silva, V. (2013). Mass transfer properties of pears for different drying methods. International Journal of Food Properties, 16(2), 251-262. http://dx.doi.org/10.1080/10942912.2011.551864

Guiné, R. P. F., Henrriques, F., \& Barroca, M. J. (2012). Mass transfer coefficients for the drying of Pumpkin (Cucurbita moschata) and dried product quality. Food and Bioprocess Technology, 5(1), 176-183. http://dx.doi.org/10.1007/s11947-0090275-y

Guiné, R. P. F., Pedro, A., Matos, J., Barracosa, P., Nunes, C., \& Gonçalves, F. J. (2017). Evaluation of phenolic compounds composition, antioxidant activity and bioavailability of phenols in dried thistle flower. Journal of Food Measurement and Characterization, 11(1), 192-203. http://dx.doi.org/10.1007/s11694-016-9386-0 
Guiné, R. P. F., Pinho, S., \& Barroca, M. J. (2011). Study of the convective drying of pumpkin (Cucurbita maxima). Food and Bioproducts Processing, 89(4), 422-428. http://dx.doi.org/10.1016/j.fbp.2010.09.001

Haghi, A. K., \& Amanifard, N. (2008). Analysis of heat and mass transfer during microwave drying of food products. Brazilian Journal of Chemical Engineering, 25(3), 491-501. http://dx.doi.org/10.1590/S0104-66322008000300007

Kroehnke, J., Szadzińska, J., Stasiak, M., Radziejewska-Kubzdela, E., Biegańska-Marecik, R., \& Musielak, G. (2018). Ultrasound- and microwave-assisted convective drying of carrots: Process kinetics and product's quality analysis. Ultrasonics Sonochemistry, 48, 249-258. PMid:30080548. http://dx.doi.org/10.1016/j.ultsonch.2018.05.040

Mohammadi, I., Tabatabaekoloor, R., \& Motevali, A. (2019). Effect of air recirculation and heat pump on mass transfer and energy parameters in drying of kiwifruit slices. Energy, 170, 149-158. http://dx.doi.org/10.1016/j.energy.2018.12.099

Mota, C. L., Luciano, C., Dias, A., Barroca, M. J., \& Guiné, R. P. F. (2010). Convective drying of onion: Kinetics and nutritional evaluation. Food and Bioproducts Processing, 88(2-3), 115-123. http://dx.doi.org/10.1016/j.fbp.2009.09.004

Nicolin, D. J., Rossoni, D. F., \& Jorge, L. M. M. (2016). Study of uncertainty in the fitting of diffusivity of Fick's Second Law of Diffusion with the use of Bootstrap Method. Journal of Food Engineering, 184, 63-68. http://dx.doi.org/10.1016/j.jfoodeng.2016.03.024

Onwude, D. I., Hashim, N., Abdan, K., Janius, R., \& Chen, G. (2019). Experimental studies and mathematical simulation of intermittent infrared and convective drying of sweet potato (Ipomoea batatas L.). Food and Bioproducts Processing, 114, 163174. http://dx.doi.org/10.1016/j.fbp.2018.12.006

Ostermeier, R., Giersemehl, P., Siemer, C., Töpfl, S., \& Jäger, H. (2018). Influence of pulsed electric field (PEF) pre-treatment on the convective drying kinetics of onions. Journal of Food Engineering, 237, 110-117. http://dx.doi.org/10.1016/j.jfoodeng.2018.05.010

Sahin, A. Z., Dincer, I., Yilbas, B. S., \& Hussain, M. M. (2002). Determination of drying times for regular multi-dimensional objects. International Journal of Heat and Mass Transfer, 45(8), 1757-1766. http://dx.doi.org/10.1016/S0017-9310(01)00273-3

Srikanth, K. S., Sharanagat, V. S., Kumar, Y., Bhadra, R., Singh, L., Nema, P. K., \& Kumar, V. (2019). Convective drying and quality attributes of elephant foot yam (Amorphophallus paeoniifolius). LWT - Food Sciente and Technlogy, 99, 8-16. http://dx.doi.org/10.1016/j.Iwt.2018.09.049

Tao, Y., Zhang, J., Jiang, S., Xu, Y., Show, P.-L., Han, Y., Ye, X., \& Ye, M. (2018). Contacting ultrasound enhanced hot-air convective drying of garlic slices: Mass transfer modeling and quality evaluation. Journal of Food Engineering, 235, 79-88. http://dx.doi.org/10.1016/j.jfoodeng.2018.04.028

Tavaria, F. K., Silva Ferreira, A. C., \& Malcata, F. X. (2004). Volatile free fatty acids as ripening indicators for Serra da Estrela Cheese. Journal of Dairy Science, 87(12), 4064-4072. PMid:15545367. http://dx.doi.org/10.3168/jds.S0022-0302(04)73548-1

Funding: Portuguese Foundation for Science and Technology (FCT)/Project reference 02/SAICT/2016/23290. 